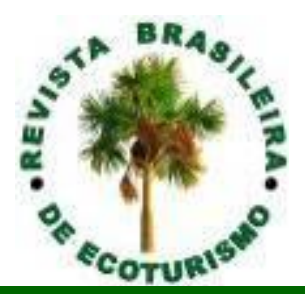

\title{
Uso público da Área de Relevante Interesse Ecológico Mata da Bica/Portalegre (RN): potencialidades e limitações
}

\section{The public use of the Area of Relevant Ecological Interest Mata da Bica/Portalegre (RN, Brazil): potentialities and limitations}

\begin{abstract}
Samylle Ruana Marinho de Medeiros, Rodrigo Guimarães de Carvalho, Geraldo Braz Silva Santos, Louize Nascimento, Francisco Hiályson Fidelis Medeiros, Antônio Helton da Silva Barbosa
\end{abstract}

RESUMO: As Unidades de Conservação instituídas no Brasil tem empreendido esforços para proteger a diversidade ecológica e cultural do país, entretanto, o uso destes espaços dissociado de políticas de manejo, conservação e sensibilização da população local e dos visitantes tem reproduzido um cenário de degradação ambiental. A Área de Relevante Interesse Ecológico Econômico (ARIE) Mata da Bica, criada no município de Portalegre, Rio Grande do Norte, Brasil, através do decreto municipal 002/2016, destaca-se pelos seus atributos naturais, representados pelas nascentes perenes, a Cachoeira do Pinga e a mata subcaducifólia associada. Apesar do potencial ambiental, a unidade não dispõe ainda do seu plano de manejo, e o uso público ocorre de maneira desordenada. Tendo em vista esta problemática, este trabalho teve por objetivo analisar o uso público da ARIE Mata da Bica e propor alternativas de uso coerentes com a conservação e 0 bem-estar social. Para isso, a coleta de dados se deteve às técnicas de georreferenciamento, registro fotográfico, check list, e aplicação de 119 questionários. Os principais resultados obtidos constataram que a maioria dos visitantes da ARIE não reside em Portalegre (77\%); e que estes, apesar de estarem visitando uma Unidade de Conservação, desconhecem o termo $(65 \%)$ e $79 \%$ não sabe o significado de ARIE; Quanto ao uso público, as atividades de educação ambiental, turismo científico e observação de aves foram eleitas como possibilidades para a Mata da Bica, que atualmente é utilizada principalmente para fins de balneabilidade e contemplação paisagística. Mediante o destaque do local como um polo turístico regional, de aspectos ecológicos relevantes, acredita-se que o diagnóstico proferido no estudo contribuirá com a construção de uma política de regulação e gestão coerente com a dinâmica do local.

PALAVRAS-CHAVE: Turismo; Planejamento Ambiental; Unidades de Conservação. 


\section{ABSTRACT}

Conservation Units established in Brazil have made efforts to protect the country's ecological and cultural diversity, however, the use of these spaces disassociated with the management, conservation and sensitization policies of the local population and visitors has reproduced a scenario of environmental degradation. The Area of Relevant Ecological Economic Interest (ARIE) Mata da Bica, created in the municipality of Portalegre, Rio Grande do Norte, Brazil, through municipal decree 002/2016, stands out for its natural attributes, represented by the perennial springs, the Pinga Water fall and the associated sub-deciduous forest. Despite the environmental potential, the unit does not have its management plan, and public use occurs in a disorderly manner. In view of this problem, the objective of this work was to analyse the public use of ARIE Mata da Bica and propose alternatives of use consistent with conservation and social welfare. For this, the data collection was the techniques of georeferencing, photographic record, checklist, and application of 119 questionnaires. The main results obtained showed that the majority of ARIE visitors do not live in Portalegre (77\%); and that these, although they are visiting a Conservation Unit, are unaware of the term (65\%) and $79 \%$ do not know the meaning of ARIE. As for public use, the activities of environmental education, scientific tourism and birdwatching were chosen as possibilities for Mata da Bica, which is currently used mainly for bathing and landscape contemplation purposes. By highlighting the place as a regional tourist pole, of relevant ecological aspects, it is believed that the diagnosis given in the study will contribute to the construction of a policy of regulation and management consistent with the dynamics of the site.

KEYWORDS: Cultural Heritage; Tourism; Archeological Ranch; Social Representations.

\section{Introdução}

A visitação em áreas naturais cresceu de maneira expressiva nos últimos anos em diversas áreas do Brasil e do mundo (MMA, 2006). A diversidade de biomas/ecossistemas e espécies, associadas à riqueza cultural, constituem atrativos singulares que potencializam o turismo no país. Grande parte destes atrativos encontra-se protegidos por Unidades de Conservação (UCs), contudo o uso destes espaços dissociado de ações de conservação e sensibilização da população local e dos visitantes tem gerado diversos problemas de degradação ambiental. Gestores e órgãos administrativos destas áreas se deparam na atualidade com o seguinte desafio: como conciliar o uso público dessas áreas com a conservação dos recursos naturais e culturais sem causar degradação? (TAKAHASHI, 2004).

A resposta para esta e outras indagações dependerá de um processo investigativo que vise diagnosticar as potencialidades e fragilidades da área em consonância com a análise do perfil do visitante. Só a partir da compreensão destas informações é possível formular normas de uso adequadas ao desenvolvimento do turismo e à conservação ambiental em áreas protegidas. 
No que diz respeito aos aspectos legais, cabe ressaltar, que, o patrimônio ambiental brasileiro tem sido resguardado por UCs desde 1934, porém foi a partir de $2000 \mathrm{com}$ a promulgação da Lei 9.985 , na qual ficou instituído o Sistema Nacional de Unidades de Conservação (SNUC), que o processo de criação e institucionalização de UC's foi fortalecido, organizado e disseminado (MMA, 2011). A Lei 9.985, além de instituir o SNUC, estabeleceu uma categorização para as UCs, disciplinou diretrizes gerais de uso e previu a criação do plano de manejo, que é o principal instrumento de gestão e regulação das áreas protegidas.

Dentre as categorias estabelecidas na legislação, encontra-se a Área de Relevante Interesse Ecológico Econômico (ARIE), cuja classificação corresponde a uma UC de Uso Sustentável, na qual o uso direto dos recursos naturais é permitido. Esta categoria de unidade consiste em uma área de pequena extensão, que apresenta pouca ou nenhuma ocupação humana, com atributos naturais extraordinários ou que contempla exemplares raros da biota regional (BRASIL, 2000).

O objetivo da ARIE é manter os ecossistemas naturais de importância regional/local e regular o uso público admissível dessas áreas, de modo a compatibilizá-lo com os objetivos de conservação da natureza (BRASIL, 2000). O conceito de uso público, aqui compreendido, está associado à visitação das áreas protegidas, em que atividades educativas, de lazer, esportivas, recreativas, científicas e de interpretação ambiental podem ser desenvolvidas, com a finalidade de proporcionar ao visitante a oportunidade de conhecer, entender e valorizar os recursos naturais e culturais existentes (MMA, 2005).

O Brasil possui atualmente 50 ARIES distribuídas no território. De acordo com o MMA (2016a) estas unidades protegem uma área de $1.020 \mathrm{~km}^{2}$. Quanto à esfera de criação, 16 unidades foram criadas no âmbito federal, 25, no âmbito estadual e 9 foram criadas pelo poder público municipal. No Bioma caatinga, as ARIES protegem $198 \mathrm{~km}^{2}$, correspondente a 5 unidades (MMA, 2016b).

No estado do Rio Grande do Norte, duas ARIES foram criadas nos últimos 3 anos, uma está situada no município de Mossoró/RN e corresponde à ARIE Ilha da Coroa, instituída através do decreto municipal no 4.158/2013. Já a outra unidade, objeto deste estudo, está localizada no município de Portalegre/RN e corresponde à ARIE Mata da Bica de Portalegre, criada através do decreto municipal 002/2016.

A ARIE Mata da Bica está inserida no polo serrano do estado e constitui uma área relevante do ponto de vista ecológico, uma vez que está inserida em uma microbacia de encosta, onde os recursos como o solo e a vegetação compõem uma conjuntura paisagística diferenciada do contexto geral do bioma caatinga, e exercem papel primordial na conservação ambiental.

A UC da Mata da Bica se destaca pelos seus atributos naturais, representados pelas nascentes perenes, a Cachoeira do Pinga e a mata subcaducifólia associada, pelos atrativos construídos, como o Terminal 
Turístico da Bica (TTB), que possui uma infraestrutura de lazer e entretenimento, e ainda, pelos atrativos culturais, por ser uma área que resguarda parte interessante da história do município, relacionada às lendas que reforçam a presença indígena no local. Todo esse aparato ecológico e cultural faz da ARIE Mata da Bica um local bastante procurado para fins de lazer e balneabilidade.

Tendo em vista que a unidade não possui ainda o seu plano de manejo e que o uso público tem ocorrido de maneira desordenada, este trabalho teve por objetivo analisar o uso público da Mata da Bica e propor alternativas de uso coerentes com a conservação e o bem-estar social.

\section{Metodologia}

\section{Localização e características gerais da área de estudo}

A ARIE Mata da Bica (Figura 1), está localizada no município de Portalegre, que se situa na mesorregião do Oeste Potiguar, sobre um maciço cristalino, a uma altitude média de $642 \mathrm{~m}$ e coordenadas $06^{\circ} 01^{\prime} 26,4^{\prime \prime}$ de latitude sul, e $37^{\circ} 59^{\prime} 16,8^{\prime \prime}$ de longitude oeste (IDEMA, 2008). O Município possui uma área territorial de $110,054 \mathrm{~km}^{2}$ (IBGE, 2014) e estabelece limites com os municípios de Riacho da Cruz, Taboleiro Grande, Viçosa, Serrinha dos Pintos, Francisco Dantas e Martins.

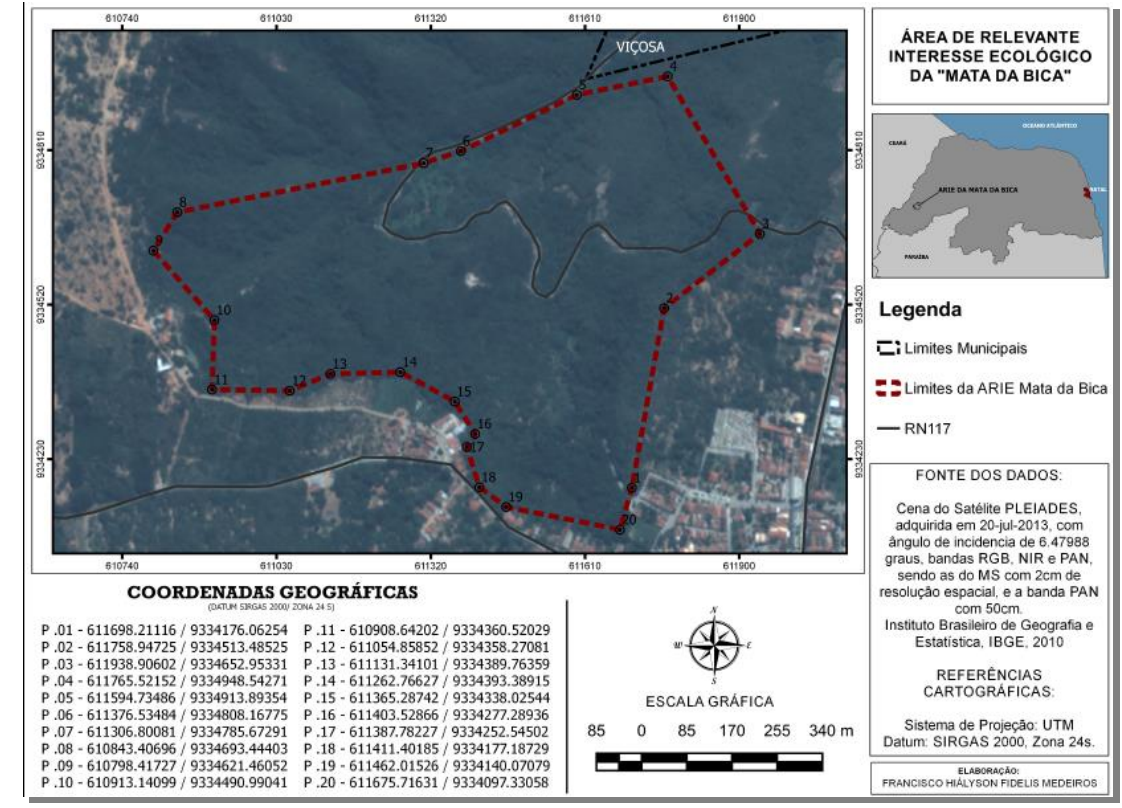

Figura 1: Localização e limites da Área de Relevante Interesse Ecológico da Mata da Bica de Portalegre/RN. Fonte: Portalegre (2016)

Figure 1: Location and limits of the Area of Relevant Ecological Interest of Mata da Bica de Portalegre/RN. Source: Portalegre (2016).

A ARIE está disposta sobre a vertente norte do município e possui uma extensão territorial de 50,66 ha, o perímetro é contemplado por uma microbacia de encosta, a qual faz parte da bacia do Rio Apodi Mossoró, estando submetida ao regime climático semiárido e às características fitogeográficas do Bioma Caatinga. Mas, ressalta-se que por estar em uma 
vertente a barlavento, a ARIE Mata da Bica de Portalegre possui uma precipitação média maior do que nas áreas circunvizinhas, o que possibilita a acumulação de água subterrânea no capeamento sedimentar do topo serrano, denominado de Formação Serra de Martins. Em virtude da sua conjuntura físico natural, a área dispõe de nascentes perenes, de uma mata sub-úmida associada aos cursos de água e um cachoeira, conhecida como Cachoeira do Pinga, cuja queda d'água está a uma altitude de aproximadamente $520 \mathrm{~m}$, e constitui o principal atrativo natural da UC.

Além dos atrativos naturais, a área possui uma estrutura física, construída para recepcionar os visitantes e proporcionar serviços de culinária e suporte de banheiros e bancos para acomodação. O TTB é bastante visitado para fins de contemplação paisagística e para desfrute do banho na "Bica", cuja fonte de água advém da nascente localizada no próprio Terminal.

\section{Etapas da Pesquisa}

\section{Levantamento bibliográfico e análise de dados secundários}

As etapas de coletas de dados primários foram subsidiadas e desenvolvidas em consonância com o levantamento bibliográfico referente à temática de uso público em unidades de conservação, além disso, o estudo se apropriou de dados secundários discutidos ao longo de pesquisas desenvolvidas nos últimos anos em Portalegre/RN, com destaque para coletânea de trabalhos publicados na obra organizada por Carvalho e Medeiros (2016), intitulada Meio Ambiente e Desenvolvimento Sustentável na Região Serrana de Martins e Portalegre, Rio Grande do Norte.

\section{Coleta de dados primários}

Os dados foram obtidos através de visitas in loco, momentos em que foram utilizadas as técnicas de georreferenciamento, registro fotográfico, check list, e aplicação de questionários. Os procedimentos técnicos adotados são detalhados a seguir:

i) Identificação dos atrativos da área: Registro fotográfico e georreferenciamento: $O$ registro fotográfico e o georreferenciamento foram utilizados para demarcar os atrativos naturais, culturais e construídos que estão presentes na Mata da Bica e que apresentam um potencial evidente de uso público. Em campo, para cada atrativo georreferenciado, foi feito o registro fotográfico, e, posteriormente, em gabinete, foi elaborado um mapa temático contendo a localização destes pontos e outros aspectos de interesse para pesquisa;

ii) Perfil e percepção ambiental dos visitantes: Aplicação de questionários semiestruturados: Para subsidiar a construção do perfil do visitante e a análise da percepção ambiental dos mesmos, foram aplicados 119 questionários semiestruturados, que correspondem à amostra de $15 \%$ do total de visitantes (jovens, adultos e idosos) que frequentaram a Mata da Bica durante o final de semana dos dias $16 \mathrm{e}$ 17 de agosto de 2016. Como na área ainda não há um sistema de 
controle de visitantes instituído, em cada local de aplicação de questionários um pesquisador se dedicou apenas a contabilizar a entrada dos visitantes, totalizando 793 visitantes que frequentaram a ARIE nos dias supracitados. Os locais de aplicação restringiram-se ao Terminal Turístico da Bica e à Cachoeira do Pinga, ambos os atrativos possuem um fluxo significativo de visitantes. No que diz respeito aos horários de aplicação, os questionários foram aplicados no turno da manhã, entre 9:00 hs e 12:00 hs, e no turno da tarde, entre 13:30hs as 16:30hs, totalizando 5 horas por dia.

iii) Análise do uso público na ARIE Mata da Bica: A análise do uso público foi realizada a partir dos apontamentos dispostos no Quadro 1. Primeiramente, buscou-se identificar os atrativos da ARIE Mata da Bica a partir das suas características preponderantes, sejam estas naturais (atrativos naturais), históricas e culturais (atrativo cultural) ou de infraestrutura (atrativos construídos).

O Check list (Quadro 1) foi elaborado visando responder as questões norteadoras da pesquisa: quais atrativos naturais, culturais e construídos existem na área? Como se dá o uso público nestes atrativos? Há uso público? Não há uso público? E se não há, existe possibilidade de uso? Nos atrativos em que há uso público, quais atividades são desenvolvidas atualmente? Há impactos evidentes? Como se dá a demanda de visitantes?

Quadro 1: Check List utilizado.

Frame 1: Check list used.

\begin{tabular}{|c|c|}
\hline IDENTIFICAÇÃO DOS ATRATIVOS & $\begin{array}{l}\text { ANÁLISE DO USO PÚBLICO } \\
\text { ATUAL E POSSIBILIDADES: }\end{array}$ \\
\hline $\begin{array}{c}\text { ATRATIVOS NATURAIS E PAISAGÍSTICOS } \\
\text { Contemplam aspectos da flora, fauna, formações geológicas, } \\
\text { corpos d'água em todas suas manifestações, cujo contato do } \\
\text { visitante com a natureza é direto. }\end{array}$ & 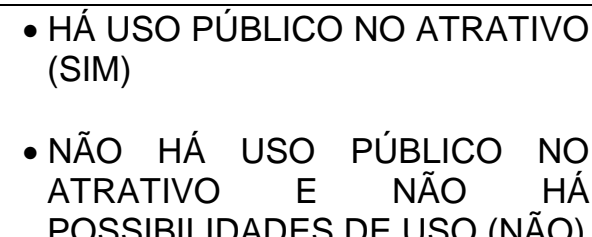 \\
\hline $\begin{array}{c}\text { ATRATIVOS HISTÓRICOS E CULTURAIS } \\
\text { São os bens e valores culturais de natureza material e } \\
\text { imaterial produzidos pelo homem e apropriados pelo turismo. }\end{array}$ & $\begin{array}{l}\text { POSSIBILIDADES DE USO (NAO) } \\
\text { - NÃO HÁ USO PÚBLICO NO } \\
\text { ATRATIVO, MAS É POSSÍVEL O }\end{array}$ \\
\hline $\begin{array}{c}\text { ATRATIVOS CONTRUÍDOS } \\
\text { São bens e imóveis construídos pelo homem e que fazem } \\
\text { parte do patrimônio material do local. }\end{array}$ & $\begin{array}{l}\text { SEU DESENVOLVIMENTO } \\
\text { (POSSIBILIDADE). }\end{array}$ \\
\hline
\end{tabular}

As questões foram respondidas a partir da percepção de três pesquisadores que desenvolvem estudos na área desde 2013, sendo um destes, geógrafo, e os demais, gestores ambientais. As respostas obtidas pela análise individual de cada pesquisador foram posteriormente interpretadas e discutidas entre eles, chegando-se a um consenso sobre as alternativas mais adequadas. 


\section{Resultados e Discussão}

\section{Perfil do visitante da Mata da Bica}

Traçar o perfil do visitante é o ponto de partida para compreender a dinâmica de visitação. No tocante à faixa etária, $51 \%$ dos visitantes têm entre 18 e 30 anos, seguido pelos $41 \%$ que possuem idade entre 31 e 59 anos e apenas $8 \%$ com mais de 60 anos, apontando uma taxa de visitação maior de pessoas mais jovens. A faixa etária refletida na ARIE da Mata da Bica de Portalegre é similar à encontrada na pesquisa de Souza e Matos (2008), realizada em uma Floresta Nacional no Estado de São Paulo, onde a maior proporção dos visitantes possui até 30 anos, seguido com os que possuem entre 30 e 50 anos. Os referidos autores justificam que essa faixa etária indica que são pessoas que vão buscar distração e descanso saindo da zona urbana e das rotinas de trabalho.

No tocante ao sexo dos visitantes, os percentuais encontrados durante a pesquisa foram de $54 \%$ do sexo masculino e $46 \%$ do sexo feminino. A respeito do grau de instrução do visitante, $70 \%$ não estudam mais e $30 \%$ ainda estão estudando. Dos que não estudam mais, $36 \%$ concluíram o ensino médio; $26 \%$ pararam de estudar no ensino fundamental; $13 \%$ possuem ensino superior completo; $10 \%$ possuem pós-graduação; $5 \%$ não terminaram 0 ensino médio; $4 \%$ representa os que possuem ensino fundamental completo; $4 \%$ também possui curso técnico e $2 \%$ pararam de estudar no ensino superior. Já na pesquisa de Souza e Matos (2008), realizada na Floresta Nacional de Ipanema, Iperó, em São Paulo a maior parte dos visitantes possuem ensino médio completo e ensino superior completo.

Estes panoramas diferentes se dão em virtude da própria conjuntura dos locais, Portalegre está situada na região Oeste do estado do Rio Grande do Norte, cuja atividade agrícola é muito presente. Em campo, durante a pesquisa, foi possível observar que grande parte dos chefes de família, aposentados atualmente, teve relação com a agricultura em algum momento de sua vida, não concluindo os estudos. Já o trabalho de Souza e Matos (2008) retrata o contexto de São Paulo, a maior metrópole do Brasil, a qual constitui um grande polo industrial, cujo mercado é altamente competitivo, refletindo positivamente no perfil escolar das pessoas.

Cabe ressaltar ainda que a análise do grau de instrução é uma importante informação quando se deseja elaborar os programas de educação ambiental, uma vez que estes devem ser adequados ao nível de escolaridade e à idade dos visitantes (KITAGAWA et al., 2013).

Quanto à ocupação/profissão dos visitantes da Mata da Bica, constatou-se que é condizente com o panorama do grau de instrução. Do total de entrevistados, $61 \%$ declararam estar trabalhando no momento e $39 \%$ responderam que não trabalham. Foram identificadas 39 ocupações diferentes, sendo as mais representativas: Servidor público, 10 entrevistados; Aposentado, com 7 pessoas; Professor com 5; e Pedreiro com 4. Outras ocupações não tão representativas foram: comerciante/empresário (3 entrevistados), motorista (3 entrevistados) e agricultor (3 entrevistados); vendedor (2 entrevistados), pastor evangélico (2 entrevistados), esteticista (2 
entrevistados), assistente administrativo (2 entrevistados) e auxiliar de escritório (2 entrevistados). Quanto às profissões/ocupações citadas apenas uma vez, constatou-se: Agente de saúde, Bombeiro, Assessor jurídico, Assistente social, Médico, Pintor, Doméstica, Publicitária, Engenheiro civil, Costureiro, Guarda civil, entre outras.

$\mathrm{Na}$ pesquisa similar realizada por Medeiros (2015) na Mata da Bica, foram identificadas 19 ocupações, mas o percentual das respostas não variou significativamente, $62 \%$ dos entrevistados trabalhavam e $38 \%$ disseram não trabalhar.

No que diz respeito à renda dos entrevistados, 69\% afirmaram possuir renda e apenas $31 \%$ disseram não possuir. A partir das respostas obtidas verificou-se que a renda mensal do visitante da ARIE Mata da Bica varia em cinco classes - $25 \%$ do total de entrevistados recebe entre 1 e 2 salários mínimos, 24\% possuem renda mensal na faixa de 2 a 4 salários mínimos, $19 \%$ recebem mais de 4 salários mínimos, 17\% recebem 1 salário e 15\% menos de um salário.

No trabalho de Campos, Vasconcelos e Félix (2011) desenvolvido no Parque Nacional da Serra do Cipó em Minas Gerais, 30\% do universo pesquisado, que correspondia ao percentual de entrevistados mais significativo da pesquisa, possuía uma renda mensal entre $R \$ 2.000,00$ e $R \$$ 4.000,00 - esta classe pode ser comparada com a classe que ganha entre $2 \mathrm{e}$ 4 salários mínimos na Mata da Bica, onde se observa um percentual menor, de $24 \%$.

Em outro estudo realizado por Aramayo e Perales (2010) no Parque das Dunas em Natal/RN, verificou-se um panorama oposto ao encontrado no Parque Nacional da Serra do Cipó, sendo a categoria menos frequente a faixa de renda de $R \$ 2.001$ a $R \$ 4.000$ e a faixa de maior representação percentual, com $33 \%$, a referente aos visitantes que possuíam renda entre $R \$ 1.001$ e $R \$ 2.000$, com relação ao grupo que recebia mais de $R \$ 4.000$, este correspondia a $15 \%$ dos visitantes do Parque das Dunas, percentual próximo do perfil encontrado na Mata da Bica, onde 19\% dos visitantes afirmaram receber mais de 4 salários mínimos.

A partir desta perspectiva, para conhecer de maneira mais aprofundada a dinâmica de visitas na ARIE Mata da Bica, buscou-se analisar a taxa de retorno do turista, se era a primeira vez que visitava a área, ou se costumava visitar com certa frequência. A pesquisa identificou que a taxa de retorno é positiva, $71 \%$ dos respondentes informaram que não é a primeira vez que frequentam o local. Com relação aos que foram à área pela primeira vez, o percentual foi de $29 \%$ dos respondentes.

Os dados obtidos apresentam similaridade com o cenário pesquisado por Medeiros (2015) na Mata da Bica, o qual apontou que 66\% eram visitantes reincidentes, que visitam a área com certa frequência e 34\% estavam no local pela primeira vez. A comparação entre os dois exercícios anuais já demonstra um suave aumento no percentual, de $5 \%$, dos entrevistados que não visitavam a Mata da Bica pela primeira vez. 
O panorama supracitado não é similar ao diagnóstico realizado com os visitantes da Gruta do Salitre em Minas Gerais, na qual 70\% dos visitantes estavam na área pela primeira vez, para Araújo, Oliveira-Júnior e Azevedo (2015) é necessário que os gestores ofereçam diversas opções de atividades envolvendo a gruta que possam motivar o retorno das pessoas, principalmente dos moradores locais. Apesar da UC de Portalegre possuir um percentual significativo de visitantes reincidentes, apenas $23 \%$ reside em Portalegre, o que reforça a importância de investimentos contínuos na área para estimular uma maior presença dos moradores locais.

Para os entrevistados que já haviam visitado a Mata da Bica em outros momentos, foi questionada a frequência com a qual se dirigiam ao local. Os resultados obtidos consistiram nos seguintes dados: $9 \%$, compõem os que frequentam 1 vez por semana; $5 \%$, são os que vão ao local mais de 1 vez por semana; $13 \%$, referente aos visitantes que frequentam a área 1 vez por mês; $5 \%$ foram aqueles que alegaram frequentar mais de 1 vez por mês; $26 \%$, correspondente aos visitantes que frequentavam a área $1 \mathrm{vez}$ a cada seis meses, em períodos que coincidem com as férias; $30 \%$ referente àqueles que vão a área 1 vez no ano; $1 \%$ frequentam a área 3 vezes ao ano; $4 \%$ frequentam 4 vezes ao ano; $6 \%$ visitam a Unidade a cada 3 anos; e $1 \%$ visitam a área a cada cinco anos.

Quanto ao período que costumam visitar a ARIE Mata da Bica, $68 \%$ dos entrevistados disseram frequentar nos finais de semana, $25 \%$ se dirigem ao local no período de férias, $3 \%$ frequentam nos feriados e $4 \%$ vão à área durante a semana. Sobre o tempo que cada visitante permanece na UC, constatou-se que cerca de $70 \%$ dos visitantes não passam mais que duas horas no local. Do total entrevistado, $44 \%$ ficam entre 1 e $2 \mathrm{~h}$, seguido de $27 \%$ que permanecem menos de $1 \mathrm{~h}$; Uma pequena parte dos visitantes permanece por maior tempo, $11 \%$ permanecem entre 2 e $3 \mathrm{~h} ; 10 \%$ passam mais de $4 \mathrm{~h}$; e $8 \%$ ficam entre 3 e $4 \mathrm{~h}$.

Sobre a procedência dos turistas que visitam as UCs, Nascimento, Ribeiro e Souza (2013) concordam que quanto mais longe da unidade os visitantes vivem, menor será o uso da área, logo será menor o número de visitas, uma vez que pode ocorrer o aumento do custo de viagem. Entretanto, aqueles que vivem mais próximos à unidade tenderão a usá-la mais (maior número de visitas), na medida em que o preço implícito de a utilizar (o custo de viagem) será menor.

Acerca dos visitantes da ARIE Mata da Bica, constatou-se que grande parte, $77 \%$, não reside em Portalegre, apenas $23 \%$ moram no município. Isso indica que a cidade possui uma potencialidade turística que ultrapassa a escala municipal. Os turistas advêm de várias localidades do Rio Grande do Norte, mas também de estados vizinhos e até de outras regiões do Brasil.

Durante a pesquisa, foram identificados visitantes de 28 cidades diferentes, sendo 21 cidades localizadas no Rio Grande do Norte e 7 cidades de outros estados. No estado do RN, as cidades que obtiveram maior expressividade quanto ao quantitativo de visitantes foram Natal, Mossoró e Pau dos Ferros. Do total de visitantes entrevistados, 19 afirmaram residir em Natal, capital do estado, cuja distância em relação ao município de Portalegre 
é de aproximadamente $370 \mathrm{Km}$; 15 relataram morar em Mossoró (distante $145 \mathrm{~km}$ de Portalegre) e $11 \mathrm{em}$ Pau dos Ferro (distante 30, $6 \mathrm{~km}$ de Portalegre).

Muitos visitantes da ARIE Mata da Bica são de municípios próximos a Portalegre, situados na mesorregião Oeste Potiguar, como Riacho da Cruz (3), Umarizal (3), Martins (3), Serrinha dos Pintos (2), Alexandria (2), Jucurutu (2) Baraúnas (2), Severiano Melo (2), entre outros municípios com apenas um visitante, como Governador Dix Sept Rosado, Tenente Ananias, José da Penha, Rafael Fernandes, Janduís, Francisco Dantas e Alto do Rodrigues. Além dos visitantes que advém da própria mesorregião da Mata da Bica, há também turistas de outros municípios do Estado do RN que não são do Oeste Potiguar, como é o caso de visitantes vindo de Parnamirim (5) e Caicó (1).

$\mathrm{Na}$ pesquisa também foram identificados visitantes de outros Estados. Foram contabilizados visitantes que residem em municípios do estado do Ceará (Fortaleza com 2 visitantes, Icapuí com 3 e Potiretama com 1), Pernambuco (2 visitantes de Recife), Distrito Federal (2 visitantes de Brasília) e Paraíba (3 visitantes de Cajazeiras e 1 visitante de Catolé do Rocha).

Levando em consideração que a maioria dos visitantes era de outras regiões, uma das questões abordava sobre como o visitante foi informado sobre 0 Terminal Turístico da Bica e a Cachoeira do Pinga. Os visitantes na maioria das respostas informaram que o conhecimento se deu através de indicação de amigos (58\%), seguido através da família que reside em Portalegre (23\%) e através da divulgação na própria cidade (10\%). Essas pessoas correspondem a $91 \%$ dos respondentes. O restante das respostas variou de divulgação na internet (5\%), divulgação da rede hoteleira, agências de viagens, viagens escolares e guias, cada um com $1 \%$.

Na pesquisa realizada por Araújo, Oliveira-Júnior e Azevedo (2015), na Gruta do Salitre, em Minas Gerais, a principal fonte de informação sobre o local eram os amigos e/ou parentes para $30 \%$ dos visitantes, o percentual mais significativo. Estes dados aferem a carência que existe nas UCs de âmbito local, em que a falta de espaços efetivos de divulgação torna a comunicação "boca a boca" uma realidade, cujos reflexos são positivos, porém destaca-se que a divulgação institucional/oficial deve ocorrer paralelamente às comunicações informais.

$\mathrm{Na}$ ARIE Mata da Bica quando questionados, posteriormente, se gostariam de receber informações sobre a UC, 76\% dos visitantes informaram que gostariam de receber informações, $24 \%$ disseram não. Diante disso, os visitantes informaram também de que maneira gostariam de ser informados, $57 \%$ optaram por ter acesso à informação por meio do site da área, seguido de $32 \%$ que gostariam que a área dispusesse de um centro de recepção de visitantes. Essas respostas juntas representam $89 \%$ do total. Os outros $11 \%$ foram divididos entre: (6\%) através de folhetos e mapas; e (5\%) por email. 


\section{Percepção ambiental dos visitantes}

A percepção do visitante é fundamental para identificar quais os pontos fortes que atraem a visita, bem como os pontos fracos que podem diminuir o interesse pela visitação. Tal diagnóstico fornece subsídio para que 0 planejamento da área seja voltado para potencializar os pontos fortes e diminuir ou eliminar os pontos fracos.

Diante disso, uma das questões buscou identificar qual o principal motivo que levou o visitante até a ARIE Mata da Bica (Qual o principal motivo que o faz visitar o Terminal Turístico da Bica?) (Quadro 2). A busca pelo lazer/balneabilidade contabilizou o maior número de respostas (52\%), seguido pela contemplação paisagística (28\%), sossego (16\%) e outros fatores (4\%) . Isso pode ser justificado principalmente pelas características naturais peculiares de um clima mais confortável, cachoeira e uma vegetação de maior porte que a ARIE Mata da Bica possui em comparação com o bioma que está inserido. Essa informação confirma o potencial de turismo ecológico da ARIE Mata da Bica, pois as atividades são realizadas em meio à natureza.

Quadro 2: Motivos que promovem a visitação na ARIE Mata da Bica.

Frame 2: Reasons that promote the visitation at ARIE Mata da Bica.

\begin{tabular}{|l|c|}
\hline \multicolumn{2}{|c|}{ Qual o principal motivo que o faz visitar a ARIE Mata da Bica? } \\
\hline Lazer/balneabilidade & 70 \\
\hline Contemplação Paisagística & 38 \\
\hline Sossego & 21 \\
\hline Histórico & 1 \\
\hline Curiosidade & 1 \\
\hline Conhecer o lugar & 3 \\
\hline
\end{tabular}

Para Souza (2016), os visitantes de unidades de conservação são movidos pelo direito assegurado de realizar algumas atividades em contato direto com a natureza. Nessa perspectiva, cabe destacar a visão de Martins (2011), o qual acredita que as áreas protegidas e os parques podem adquirir um papel relevante na construção de um novo valor da natureza, pois as populações urbanas procuram a natureza para práticas de recreação, comtemplação de paisagens, observação de vida silvestre, entre outras coisas.

O aumento da urbanização possui uma relação direta com a conservação da natureza, na medida em que a necessidade de fuga da metrópole cria as condições para que a natureza ocupe um novo lugar no sistema de valores e o lazer seja um modo de sensibilização deste valor. Para a conservação, as áreas protegidas detêm a missão de aliar as necessidades da preservação biológica, na ideia de "refúgio da natureza", às necessidades de bem-estar social com a experiência da "fuga da metrópole" (MARTINS, 2011).

Kitagawa et al. (2013), ao analisar o perfil dos visitantes do Parque Natural Municipal da Taquara, em Duque de Caxias, no Rio de Janeiro, verificaram que o principal motivo que levava os visitantes a frequentar a 
área, eleito pela maioria entrevistada (39\%), era o banho de rio e cachoeira, semelhante à resposta encontrada na ARIE Mata da Bica.

Essa informação difere um pouco da pesquisa realizada por Souza e Matos (2008), onde o contato com a natureza foi tido como o principal motivo para procura nas trilhas da Floresta Nacional de Ipanema, em São Paulo, para $30 \%$ dos respondentes, o lazer ficou apenas com 8,9\%. Além disso, os visitantes desejam encontrar nas trilhas da Flona de Ipanema, a Flora e Fauna (41\%), Natureza/Paisagem (33,9\%) e tranquilidade apenas 8,9\%.

Os motivos que levam à visitação podem ser explicados pela descrição positiva que os visitantes atribuíram à ARIE Mata da Bica, onde as respostas foram categorizadas em três características chaves - aspectos naturais, de beleza/bem estar e também de singularidade da área em relação ao seu entorno. Cabe ressaltar que a quantidade de respostas obtidas não reflete a quantidade exata de questionários aplicados, uma vez que alguns entrevistados caracterizaram a área citando mais de um aspecto (Quadro 3).

Quadro 3: Descrição positiva da ARIE Mata da Bica, segundo os visitantes.

Frame 3: Positive description of ARIE Mata da Bica, according to visitors.

\begin{tabular}{|l|c|l|c|c|c|}
\hline \multicolumn{1}{|c|}{$\begin{array}{c}\text { ASPECTOS } \\
\text { NATURAIS }\end{array}$} & $\begin{array}{c}\text { Quantidade } \\
\text { de respostas }\end{array}$ & $\begin{array}{c}\text { ASPECTOS DE BELEZA } \\
\text { /BEM ESTAR }\end{array}$ & $\begin{array}{c}\text { Quantidade } \\
\text { de respostas }\end{array}$ & $\begin{array}{c}\text { ASPECTOS DE } \\
\text { SINGULARIDADE }\end{array}$ & $\begin{array}{c}\text { Quanti- } \\
\text { dade de } \\
\text { respostas }\end{array}$ \\
\hline $\begin{array}{l}\text { Um lugar de } \\
\text { riquezas naturais }\end{array}$ & 6 & $\begin{array}{l}\text { Um lugar } \\
\text { bom/ótimo }\end{array}$ & 47 & $\begin{array}{l}\text { Um lugar Diferen- } \\
\text { te do contexto do } \\
\text { Sertão nordestino }\end{array}$ & 2 \\
\hline $\begin{array}{l}\text { Um lugar de Clima } \\
\text { agradável }\end{array}$ & 8 & $\begin{array}{l}\text { Um lugar Tranquilo/Sosse- } \\
\text { gado/Para Relaxar }\end{array}$ & 21 & & \\
\hline Um lugar arborizado & 1 & Encantador & 1 & & \\
\hline $\begin{array}{l}\text { Um lugar de contato } \\
\text { com a natureza } \\
\text { preservada }\end{array}$ & 5 & $\begin{array}{l}\text { Um lugar Maravilhoso/Mag- } \\
\text { nifico/Excepcional/Paradisíaco }\end{array}$ & 9 & & \\
\hline & & Bonito/Lindo & 32 & & \\
\hline & & Agradável/Aconchegante & 9 & & \\
\hline & & Um lugar de Lazer/Divertido & 2 & & \\
\hline
\end{tabular}

A maioria das respostas que descreveram os pontos positivos foi relacionada aos aspectos de beleza/bem-estar, fortalecendo o argumento de ser uma área diferencial para proporcionar atividades de lazer, contabilizando 123 respostas. Os aspectos naturais também foram levados em conta e totalizaram 20 respostas, onde o fator clima agradável chegou a quase metade das respostas, evidenciando se tratar de uma área que apresenta um conforto térmico, o que já foi mensurado no estudo de Silveira e Carvalho (2016). Além disso, os aspectos de singularidade registraram duas respostas, tratando a ARIE Mata da Bica como um lugar diferente do contexto geral do sertão nordestino.

A descrição positiva da área se dá principalmente pelas características de ser um local agradável, preservado e que fornece uma possibilidade de lazer em contato com a natureza. Entretanto, também existem aspectos 
desagradáveis que podem comprometer uma visitação futura, que se consideraram as descrições negativas. Os visitantes afirmaram que a ARIE Mata da Bica "precisa de cuidados", está "sujo" e até que "precisa de mudanças na administração/infraestrutura".

Quando perguntados aos entrevistados se estes estavam satisfeitos com a infraestrutura e serviços do local (O Sr. (a) está satisfeito com a estrutura e serviços do local?), $63 \%$ dos visitantes responderam que "sim" e $37 \%$ responderam que "não". Os visitantes que responderam não estar satisfeitos recomendaram uma série de medidas para melhorar a qualidade da visitação. No tocante à infraestrutura, 50 medidas foram citadas, categorizadas nas seguintes respostas: "a construção de bares e lanchonetes"; "construção de um espaço infantil";" construção de um centro de informações"; "investir em acessibilidade para deficientes"; "melhorar o acesso ao local"; "investir na construção de um estacionamento para Cachoeira do Pinga"; "Melhorar as passarelas e pontes"; Quando aos serviços, 23 respostas foram contabilizadas, estas foram agrupadas nas seguintes respostas: "melhorar a organização/gestão da área"; "melhorar a sinalização, com placas informativas dentro da UC"; "melhorar a segurança local" e "melhorar a limpeza".

Das respostas obtidas, os principais pontos abordados pelos visitantes que necessitam de melhoria foram: dispor de um estacionamento (citado 11 vezes), melhorar as passarelas/pontes (11 vezes) e melhorar a limpeza do local (10 vezes). Uma pergunta similar realizada por Oliveira et al (2015) no estudo sobre o perfil, a percepção e a opinião dos visitantes do Parque Nacional do Itatiaia, no Rio de Janeiro, menos de $20 \%$ dos entrevistados relataram observar aspectos negativos, que carecem de melhoria, dentre os quais se destacou a condição da estrada de acesso aos atrativos, que corrobora com a percepção dos visitantes da Mata da Bica, quanto à estrutura de passarelas e pontes que levam até a Cachoeira do Pinga. As sugestões de melhoria que foram citadas apenas uma vez foram agrupadas em "outros": como por exemplo - "Deveria ter guias"; "Manutenção"; "Ser mais moderno"; "Ter piscina no local"; "Melhoria de atendimento no restaurante".

Além das medidas de melhoria, os visitantes foram questionados se observavam problemas ambientais na ARIE Mata da Bica ( $O$ Sr.(a) observa a existência de problemas ambientais na área?) A maior parte dos visitantes (57\%) afirmou não observar problemas ambientais na ARIE Mata da Bica, enquanto que $43 \%$ disseram observar sim problemas ambientais. Para este último grupo foi perguntado quais os problemas ambientais que eles identificaram durante a visita, onde se observa que o problema mais citado diz respeito à má disposição de resíduos sólidos (citado 24 vezes), seguido de "Degradação Ambiental" (citado 2 vezes) e "Queimadas" (2 vezes), outras respostas como "Erosão", "Estrutura do local", "Animais domésticos no local", "Água suja", "Pouca quantidade de água", "lavagem de moto" e "Espelho d'água poluído" também foram citadas.

O lixo gerado pela visitação e não descartado adequadamente e no tempo devido acarreta prejuízos à biodiversidade local e à qualidade dos recursos naturais, podendo trazer diversos problemas para a fauna, tais como 
a poluição de hábitats, a ingestão de materiais não digeríveis, como o plástico e a intoxicação alimentar. A poluição é capaz de impactar diretamente a atividade de "contemplação paisagística" e outras, variáveis do uso público (PONTES; MELO, 2013).

Esses problemas interferem diretamente no grau de satisfação do visitante, onde $78 \%$ dos visitantes afirmaram se sentir incomodados pelos problemas ambientais observados. Apenas $22 \%$ disseram não se incomodar. Com exceção das respostas "erosão no local" e "Pouca quantidade de água", que podem ser atribuídos a aspectos naturais, como a declividade e o clima, todas as outras respostas são atribuídas à interferência antrópica no local. Sendo assim, os usuários do local podem ser o principal agente degradador.

Diante disso, uma das questões proferidas foi sobre o que o visitante tem feito para contribuir com a conservação do local ( $O$ que o Sr. (a) tem feito para contribuir com a conservação do local?). Os visitantes responderam que contribuem "não descartando lixo" (citada 31 vezes), as outras respostas, relatadas nove vezes, consistiram em: "preserva a natureza"; "sensibiliza outros visitantes"; "não polui os recursos hídricos"; e "não faz nada, pois é responsabilidade da administração pública". Porém, o problema ambiental mais observado foi o descarte de resíduos no local. Há uma divergência, portanto, entre a conduta do visitante e o cenário da ARIE, é certo que a responsabilidade pela educação e gestão dos resíduos recai sobre todos poder público, visitantes e iniciativa privada que atua na área - contudo é o poder público o principal responsável pela limpeza e manutenção da área, o qual dispõe de um zelador pra fazer o serviço.

Na Mata da Bica, em 2015, o trabalho desenvolvido por Medeiros (2015) revelou que $83 \%$ dos entrevistados afirmaram "não jogar o lixo no chão" para contribuir com a conservação do local, um resultado coerente com os dados discutidos aqui. Na pesquisa realizada por Souza e Matos (2008) os visitantes também responderam, em sua maioria, que contribuem para diminuição dos impactos ambientais nas trilhas "não jogando lixo". O que induz a acreditar que esta ação está cada vez mais presente em áreas naturais, os visitantes se sentem sensibilizados a "conservar o local", seja em virtude da própria concepção do turismo ecológico ou mesmo dos programas e placas de educação ambiental que são implementadas nas UCs.

Por estarem em uma Unidade de Conservação, os visitantes foram questionados, posteriormente, se já tinham ouvido falar em UCs. A maioria $(65 \%)$ nunca ouviu falar em UCs, mas $35 \%$ já ouviram falar. A maioria também respondeu a respeito do significado de Área de Relevante Interesse Ecológico - ARIE, onde $79 \%$ não sabem o que significa e apenas $21 \%$ sabe do que se trata. Esses dados ressaltam a necessidade de condutores que trabalhem a conscientização e educação ambiental dos visitantes.

Considerando que a maioria da demanda de melhoria necessita de recursos financeiros, os visitantes foram perguntados se estariam dispostos a pagar caso fosse cobrado um valor para ter acesso ao local. Grande parte dos turistas demonstrou sensibilidade a essa necessidade e responderam que 
sim $(80 \%)$, sendo que $20 \%$ responderam que não, visto que é uma área pública e o poder público detém a responsabilidade de realizar a manutenção.

Para o percentual que respondeu estar disposto a pagar uma taxa pecuniária para entrar na UC foi feito o seguinte questionamento: "quanto estaria disposto a pagar para ter acesso ao local" para esta pergunta $80 \%$ dos entrevistados afirmaram estarem dispostos a pagar de $R \$ 1$ a $R \$ 5 ; 15 \%$ dos visitantes disseram poder pagar entre $R \$ 5-R \$ 10$; e apenas $5 \%$ informou poder pagar de $\mathrm{R} \$ 10-\mathrm{R} \$ 15$.

O trabalho de Volanova, Chichorro e Arruda (2010) no Parque da Cidade Mãe Bonifácia, em Cuiabá, Mato Grosso, verificou que 27,5\% dos entrevistados estariam dispostos a pagar um valor de entrada para a manutenção do Parque, sendo que a classe de valor que obteve a maior frequência foi a de $R \$ 0,50$ a $R \$ 1,00$, com $82,1 \%$ da preferência dos entrevistados dispostos a pagar.

Nos dois contextos abordados, seja na ARIE Mata da Bica ou no Parque da Cidade Mãe Bonifácia, é possível observar que a taxa que a maioria dos visitantes concorda corresponde a um valor simbólico que não restringe significativamente o caráter democrático desses espaços.

Outra experiência semelhante de investigação, realizada por Randrianarison e Wätzold (2016) em Antananarivo, cidade mais populosa de Madagascar, um país situado no continente africano, evidenciou a disposição dos cidadãos locais de pagar pela conservação das florestas espinhosas endêmicas no sudoeste de Madagáscar, para os autores supracitados o pagamento para usufruir de espaços naturais é uma tendência que tem crescido no mundo todo, à medida que se reconhece a relevância de manter as florestas e seus serviços ambientais.

\section{Uso Público Atual e Possibilidades}

O termo uso público é empregado para se referir à utilização e aproveitamento das UCs, por meio da visitação e de outras formas de uso a esta associada, independentemente da motivação do visitante contemplação, recreação, esporte, observação de aves, entre outros, ou do segmento do turismo em questão, seja um turismo ecológico, histórico ou urbano (MEDEIROS et al., 2011). Conforme definiu Simonetti e Nascimento (2013), as diferentes possibilidades de uso público em áreas protegidas potencializa o turismo, constituindo assim uma estratégia favorável para o desenvolvimento da região na qual a unidade está inserida.

Em uma escala mais abrangente, o estudo de Souza (2016) corrobora com essa perspectiva de geração de renda e oportunidades, uma vez que destaca que no Brasil o turismo em UCs movimenta aproximadamente $R \$ 4$ bilhões por ano, gera 43 mil empregos e agrega $R \$ 1,5$ bilhão ao Produto Interno Bruto (PIB).

No tocante aos custos e benefícios gerados pelas UCs, Larson et al (2016) faz uma ressalva quanto a sua distribuição na comunidade, alertando para que esta ocorra de maneira igualitária e equitativa, pois a distribuição desigual de custos e benefícios nas comunidades que cercam áreas 
protegidas pode afetar negativamente os meios de subsistência, aumentar as disparidades de riqueza e criar conflitos.

Todavia, o grande desafio para os gestores de áreas protegidas, além de gerir os recursos econômicos, é gerir os recursos naturais, que dizem respeito às potencialidades do próprio ambiente, e culturais, que refletem o patrimônio imaterial da área. A gestão dos recursos naturais e culturais passa primeiro pela definição do uso público ideal, tal decisão dependerá de um diagnóstico prévio da área, que identifique e analise os atrativos naturais, histórico/culturais e construídos que se façam presentes no local, além disso, o levantamento da demanda e anseios dos visitantes se faz necessário, tendo em vista que o uso público deve ser pensado na perspectiva de promover a conservação ambiental e o bem estar da coletividade que frequenta a UC.

Hearner e Salinas (2002) ao estudarem as preferências turísticas para o desenvolvimento do ecoturismo na Costa Rica, enfatizaram que os tomadores de decisão precisam entender e incorporar preferências turísticas para a apreciação da natureza, infraestrutura, restrições de uso, entre outras questões que dizem respeito ao uso público.

Desse modo, infere-se que tanto o atrativo como o usuário deve ser compreendido. Do ponto de vista dos seus atrativos, a Mata da Bica se destaca pelo Terminal Turístico da Bica (TTB), um local construído para receber os visitantes e moradores para prática do lazer. No TTB, além da estrutura física de restaurante e bancos, estão situadas fontes de água perenes, tal fator natural possibilita o uso frequente dos moradores para coletar água, a qual é utilizada no consumo próprio das atividades domésticas ou na dessedentação de animais. No TTB há ainda a prática do banho na Bica, cuja fonte de água advém das nascentes perenes do local (Figura 2).

A

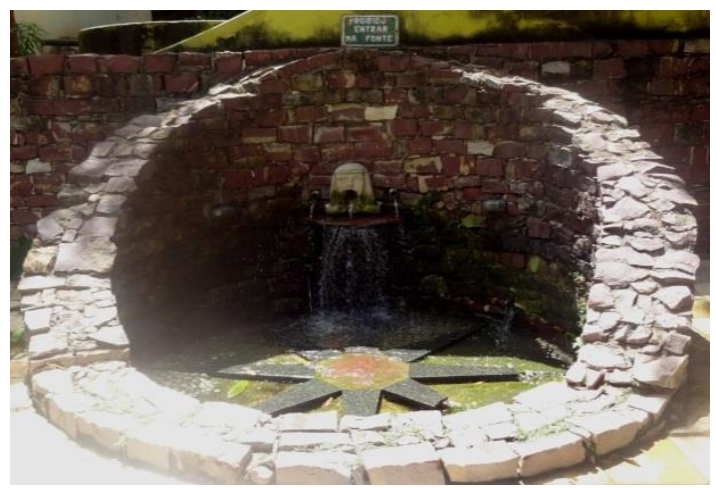

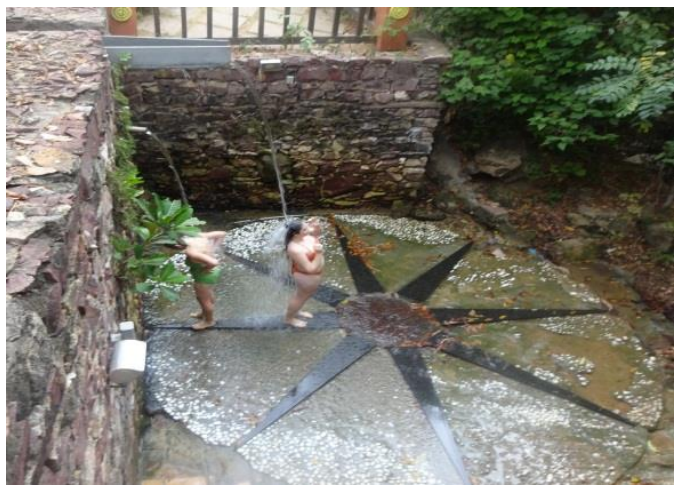

Figura 2: terminal turístico da bica. a) fonte de água. b) bica - tradicional banho da população local e ponto turístico a $600 \mathrm{~m}$ de altitude.

Fonte: banco de imagens do laboratório integrado de análise ambiental e ecologia aplicada, Universidade do Estado do Rio Grande do Norte, 2013.

Figure 2: bica tourist terminal. a) water source. b) bica - traditional bath of the local population and tourist point to $600 \mathrm{~ms}$ of altitude.

Source: integrated laboratory of environmental analysis and applied ecology, State University of Rio Grande do Norte. 
No que diz respeito às potencialidades do município, os visitantes da Mata da Bica foram questionados se conheciam outros atrativos além do TTB (Além do Terminal Turístico da Bica conhece outros atrativos de Portalegre$R M$ ), para o questionamento $78 \%$ dos entrevistados responderam que sim, e $22 \%$ responderam que não. O principal motivo que impossibilita um maior número de visitantes de conhecer outras áreas relevantes do município se dá pela dificuldade de comunicação sobre os acessos e falta de placas informativas.

No estudo de Barbosa (2013), desenvolvido na ARIE Floresta da Cicuta localizada em Volta Redonda, Rio de Janeiro, foi identificado que propriedades privadas estavam interferindo no fluxo de visitantes à UC, conforme evidenciado no trabalho o problema do acesso à área precisa ser equacionado para facilitar o uso mais abrangente pela população, sem tantas restrições. Esta situação também já foi evidenciada em Portalegre/RN, onde propriedades privadas dificultam o acesso a algumas áreas de nascentes.

No tocante aos entrevistados que disseram conhecer outros atrativos além do TTB, verificou-se que grande parte conhece a Cachoeira do Pinga e os Mirantes, conforme o Gráfico 1. Estes locais, em específico, possuem acesso fácil, o que os tornam mais conhecidos.

- Quantidade de entrevistados que conhecem os respectivos atrativos

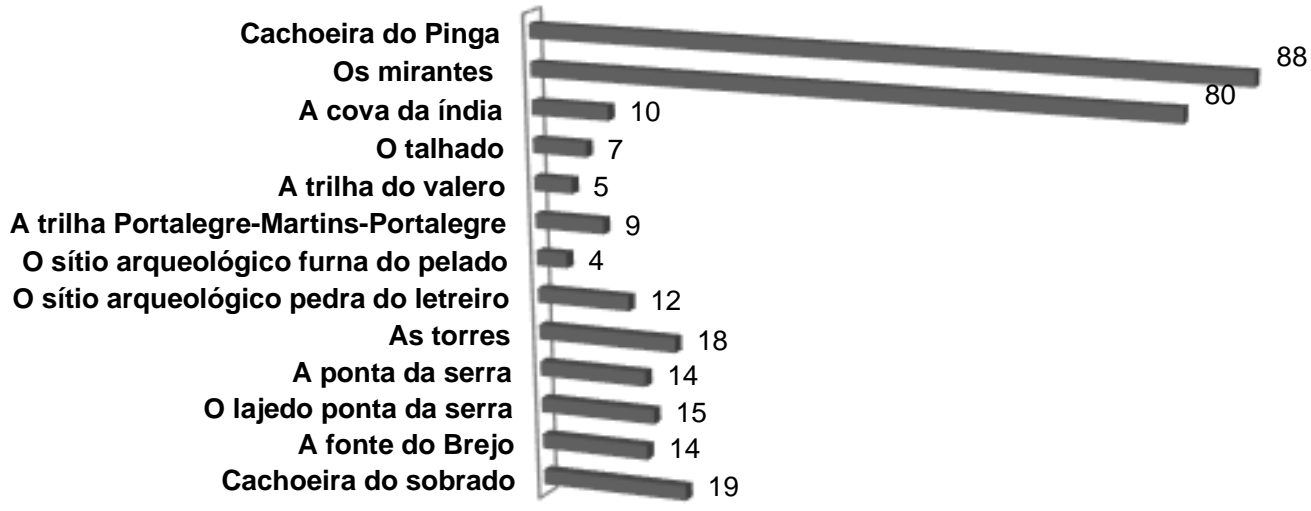

Gráfico 1: Atrativos de Portalegre conhecidos pelos visitantes da ARIE Mata da Bica. Graphic 1: Attractions of Portalegre known by visitors of ARIE Mata da Bica.

Na UC da Mata da Bica, foram identificados, além do TTB, três atrativos, totalizando quatro pontos dentro da unidade que são passíveis de visitação e uso público (Figura 3), são estes: o Terminal Turístico da Bica, citado anteriormente, localizado a $620 \mathrm{~m}$ de altitude, cujo ponto apresenta as 
nascentes perenes e a Bica, a qual é utilizada para banho; o Riacho da Bica, um córrego que ocorre dentro da área a partir de $570 \mathrm{~m}$ de altitude; a Cachoeira do Pinga, que situa-se a 450m de altitude, e a Cova da Índia, uma área que há no interior da Mata da Bica em que não nasce vegetação, e que além da sua relevância natural, constitui um ícone histórico e cultural, que configura o cenário da lenda indígena de "Cantofa e Jandy", a qual faz referência à luta indígena pela posse da terra.

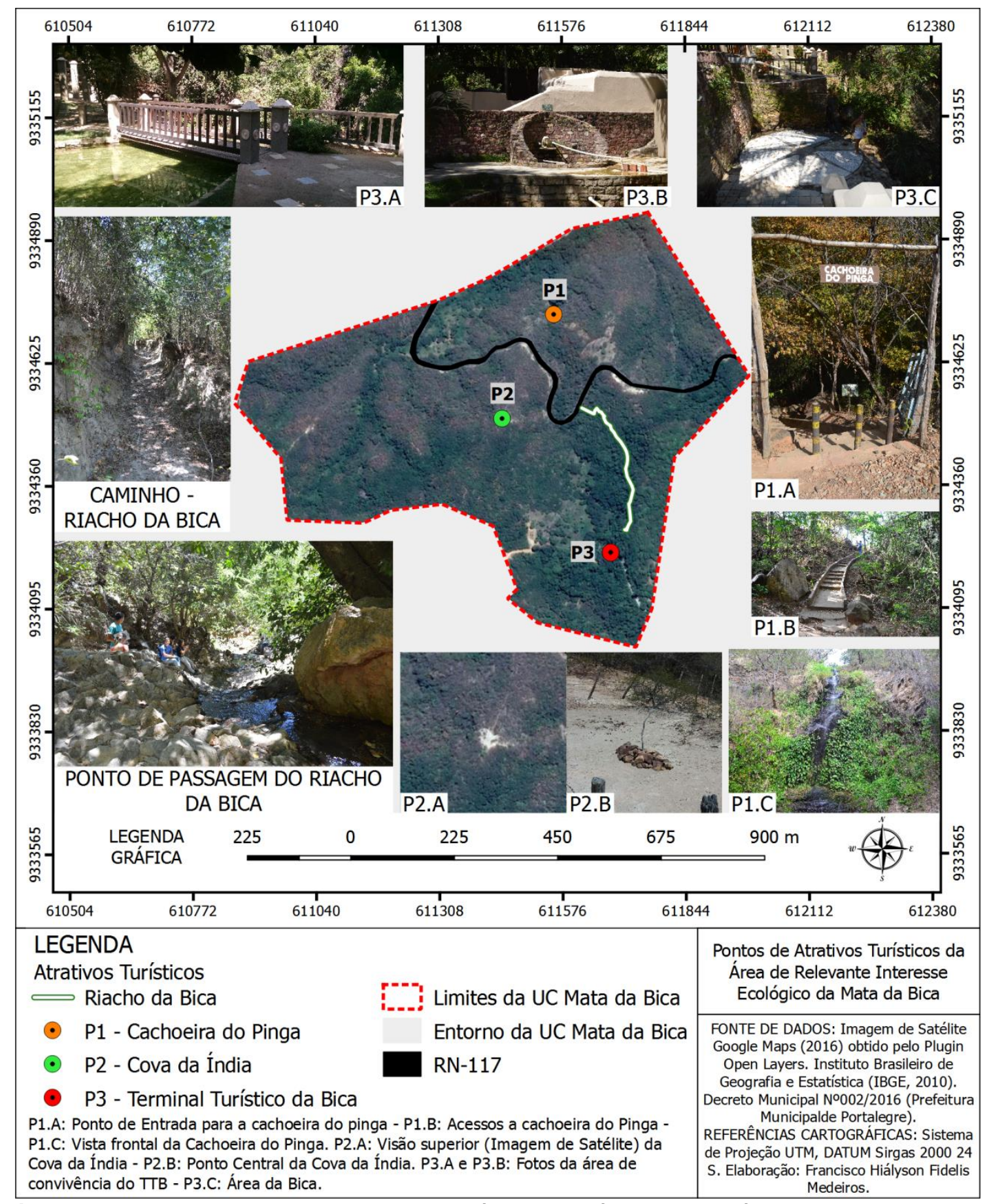

Figura 3: Mapa de localização dos atrativos turísticos passíveis de uso público na Mata da Bica.

Figure 3 - Location map of the tourist attractions that can be used publicly in Mata da Bica. 
Segundo a estória, a índia Cantofa teria sido assassinada na presença de sua neta Jandy enquanto rezava o ofício de Nossa Senhora. Logo após o acontecido, Jandy não foi mais encontrada. Contam os antigos que o local ficou mal assombrando, podendo se ouvir pela madrugada vozes, seja de alguém rezando, ou mesmo de um choro. A Cova da Índia é, portanto, o lugar em que se acredita ter sido enterrada a índia Cantofa (VIANA; NASCIMENTO, 2009).

Sobre as potencialidades turísticas dos atrativos citados, Viana e Nascimento (2009) destacam que a fauna e a flora nativa, característica do Brejo de Altitude, apresenta biodiversidade diferenciada da vegetação semiárida que a cerca, tornando o ambiente propício para a prática do ecoturismo, além disso as rochas (granitos) e a geomorfologia da área permitem a prática do geoturismo. Quanto ao turismo de aventura, os autores ressaltam que pode ser praticado através do rapel, da escalada e do cachoeirismo, alertando, todavia, para o perigo existente na prática desse segmento do turismo, em virtude da insegurança encontrada tanto no que diz respeito à dinâmica geomorfológica de desagregação e transporte de sedimentos e rochas, por se tratar de uma área de declive, como também pela falta de estrutura e profissionais para acompanhar o desenvolvimento da atividade.

Contudo, baseada nas ponderações relatadas e na visão dos profissionais que analisaram a área da Mata da Bica durante a pesquisa a partir do Check List, foi possível fazer o levantamento dos atrativos que estão inseridos na ARIE Mata da Bica e apontar possíveis alternativas de uso viáveis para o contexto atual. O Quadro 4 (próxima página) expõe a análise obtida.

Para os profissionais consultados, a educação ambiental deve estar presente como alternativa em todos os pontos, essa prática é fundamental para sensibilizar os visitantes quanto ao papel que as áreas protegidas exercem, despertando-os para um novo olhar acerca dos recursos naturais e de sua conservação. Entretanto, as ações educativas para serem desenvolvidas exigem preparação. De acordo com Valenti et al (2012) é necessário que haja processos de formação continuada de educadoras/es ambientais que atuam nas UCs, além de estratégias que proporcionem maior repercussão das políticas públicas em seu trabalho cotidiano.

Uma das principais finalidades da educação ambiental consiste em induzir novas formas de conduta nos indivíduos e na sociedade, a respeito do meio-ambiente e propiciar, a todas as pessoas, os conhecimentos, o sentido dos valores, 0 interesse ativo e as atitudes necessárias para protegerem e melhorarem o meio-ambiente (AMARAL; MUNHOZ, 2007).

O Ministério do Meio Ambiente, em sua publicação acerca da educação ambiental em UCs, aposta em um modelo crítico e emancipatório, que integre os autores e iniciativas locais.

A educação ambiental crítica e emancipatória deve permear as práticas educativas no interior e no entorno de áreas protegidas. Os educandos e educadores dessas áreas, 
especialmente aquelas isoladas e com menos apoio, clamam por oportunidades. É preciso investir em modelos simples e inovadores de educação. Faz-se necessário promover 0 fortalecimento da participação social na gestão da biodiversidade, primando pela equidade de gênero, protagonismo do jovem e dos atores em vulnerabilidade ambiental e pela identidade local dos projetos (MMA,2016, p.11)

Quadro 4: Análise do uso público atual e possível na ARIE Mata da Bica.

Frame 4: Analysis of current and possible public use at ARIE Mata da Bica.

\begin{tabular}{|c|c|c|}
\hline ATRATIVOS & USO PÚBLICO ATUAL & POSSIBILIDADES DE USO \\
\hline $\begin{array}{l}\text { TERMINAL TURÍSTICO DA BICA } \\
\text {. }\end{array}$ & $\begin{array}{l}\text { Contemplação } \\
\text { paisagística; Pesquisa } \\
\text { Científica; } \\
\text { Piquenique; } \\
\text { Banho na Bica; e Culinária } \\
\text { através do uso do } \\
\text { restaurante que há na } \\
\text { área. }\end{array}$ & $\begin{array}{l}\text { Educação Ambiental e } \\
\text { observação de aves }\end{array}$ \\
\hline IACHO DA BICA & $\begin{array}{l}\text { Contemplação paisagística } \\
\text { e balneabilidade. }\end{array}$ & $\begin{array}{l}\text { Educação ambiental; } \\
\text { Turismo científico e } \\
\text { observação de aves }\end{array}$ \\
\hline CACHOEIRA DO PINGA & $\begin{array}{l}\text { Balneabilidade; } \\
\text { Contemplação } \\
\text { paisagística; Piquenique e } \\
\text { pesquisa. }\end{array}$ & $\begin{array}{l}\text { Educação ambiental e } \\
\text { Turismo científico. } \\
\text { No topo da cachoeira há } \\
\text { possibilidade de construir um } \\
\text { mirante e realizar atividades } \\
\text { de rapel. }\end{array}$ \\
\hline COVA DA & Não há uso público atual. & $\begin{array}{l}\text { Mirante, educação ambiental } \\
\text { e abordagens culturais. }\end{array}$ \\
\hline
\end{tabular}


Para o TTB e o Riacho da Bica, foi sugerida, além da educação ambiental, a observação de aves ou birdwatching, esta atividade turística segue o viés contemplativo do ecoturismo, e se baseia na observação das aves no seu meio natural. Esta opção vai desde a observação simples, a partir do uso de binóculos e telescópios de campo, até outras variantes como a fotografia, a pintura e a ilustração da natureza (DIAS; FILGUEIRA, 2010). A prática do birdwatching, apesar de atingir um público específico, tem ganhado cada vez mais adesão no mundo todo. No Brasil, a observação de aves ainda está dando seus primeiros passos quando comparado a alguns países da América do Norte e Europa, especialmente os EUA, Inglaterra e Alemanha (CASTILHO; GOMES, 2017). Para Castilho e Gomes (2017), o número de brasileiros envolvidos nessa atividade de lazer ainda é pequeno. Complementando tal constatação, Farias (2007) expõe que a observação de aves é mais comum entre pessoas do meio acadêmico, principalmente entre os biólogos, por questões geralmente associadas a interesses científicos ou por conta de uma "filosofia ambiental" (Quadro 4).

Outras alternativas retratadas no quadro supracitado dizem respeito ao turismo científico, à construção de mirantes, e a abordagens culturais. $O$ turismo científico proposto para o atrativo da Cachoeira do Pinga, se adequa também aos demais atrativos, uma vez que este visa atender aos anseios de grupos de pesquisadores e alunos dispostos a entender a dinâmica ambiental da área; já a possibilidade de construção de mirantes no topo da Cachoeira e na Cova da Îndia incrementaria a visualização da bela paisagem que se tem a partir dessas áreas, todavia, cabe relatar que atualmente não há acesso seguro para estes locais, nem infraestrutura básica que possibilite a contemplação paisagística a partir desses pontos.

Quanto à alternativa de desenvolver abordagens culturais, esta foi pensada para Cova da Índia, pois o local faz referência ao cenário que dá vida à lenda de Cantofa e Jandy, já retratada neste artigo, a abordagem cultural neste atrativo poderia enaltecer a lenda e outras estórias que se tenham de povos que ali habitaram.

A proposição das alternativas de uso pelos pesquisadores consultados visa, sobretudo, promover a sustentabilidade ecológica e cultural, tão idealizada e pouco efetiva nas UCs do Brasil. Em uma análise feita por Melo, Lins e Eloy (2014) em um estudo sobre o impacto do turismo em ambientes recifais na praia de Seixas-Penha, na Paraíba, Brasil observa-se que a sustentabilidade ecológica ainda é um objetivo a se buscar, pois não foram estabelecidos limites ou qualquer ação pública e/ou privada direcionada a planejar o turismo e a recreação no local.

Dado o destaque às possibilidades de uso sugeridas pelos pesquisadores, cabe aqui, abordar a opinião dos frequentadores da área. Para Bellinassi e Cardoso (2011), a visitação pública da comunidade e de turistas é uma ferramenta que promove a valorização dos recursos naturais e socioculturais das áreas protegidas. Neste sentido, pensando no bem estar social e na promoção da conservação dos recursos foram questionados aos visitantes da ARIE Mata da Bica as suas preferências quanto às atividades a serem desenvolvidas, analisando inclusive, o grau de interesse (dentre as 
atividades que podem ser desenvolvidas na ARIE, quais despertam o seu interesse - elenque de acordo com o grau de interesse: Tem muito interesse (4); Tem interesse (3); Tem pouco interesse (2); Não tem interesse (1)).

As respostas para a pergunta foram reproduzidas no Gráfico 2, a partir do qual observa-se que o banho em riachos e cachoeiras, a observação da fauna e flora e a contemplação paisagística despertam significamente o interesse dos visitantes, uma vez que mais de 60 visitantes declararam ter muito interesse. Cabe ressaltar que tanto o banho como a contemplação paisagística são atividades que já existem no local, porém sem nenhuma regulamentação ou planejamento, os próprios visitantes, de maneira independente, usufruem da área. Todavia, para o gestor municipal, cabe o desafio de institucionalizá-las, tornando-as parte do portfólio de atividades da ARIE, para isso, não há uma dificuldade acentuada, uma vez que essas atividades não demandam um custo exorbitante com recursos humanos e materiais.

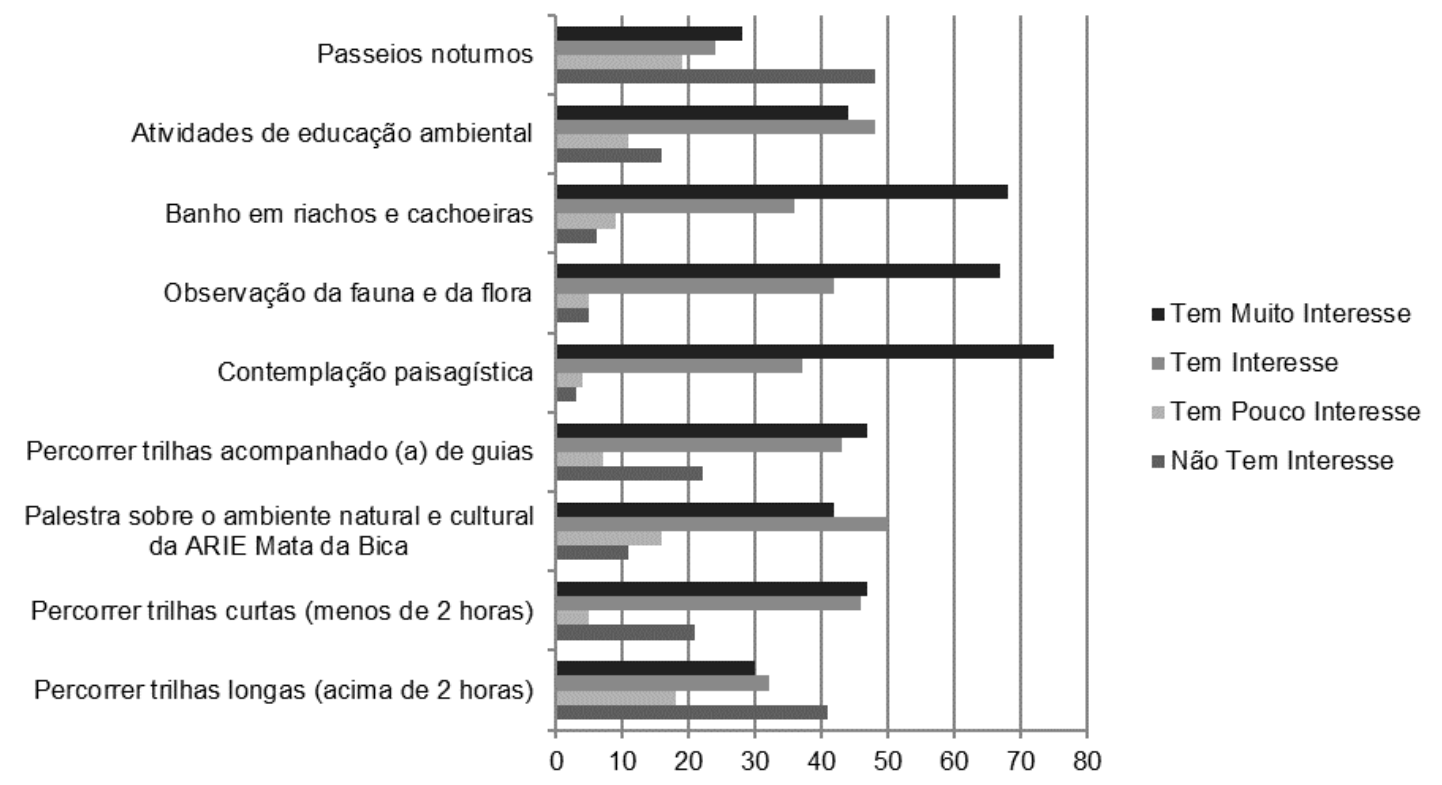

Gráfico 2: Grau de interesse dos visitantes por atividades turísticas. Graph 2: Interest rate of visitors by tourist activities.

Outras atividades, como passeios noturnos e percorrer trilhas longas (acima de 2 horas) não despertaram desejo na maioria dos visitantes, uma vez que nas duas opções mais de 40 visitantes declararam não ter interesse, se sobressaindo sobre os demais quantitativos.

No trabalho de Campos, Vasconcelos e Félix (2011) realizado no Parque Nacional da Serra do Cipó, o item de maior interesse relatado pelos visitantes foi o banho em rios e/ou cachoeiras, seguido de caminhadas longas (mais de duas horas de duração) e observação da paisagem, associada ao registro fotográfico da mesma. Neste viés, verifica-se certa semelhança entre as preferências correlatadas dos turistas da Serra do Cipó e da M.B, apenas 
com exceção para o interesse por caminhadas longas, que na M.B não despertou interesse significativo.

Campos, Vasconcelos e Félix (2011) identificaram ainda atividades que despertam um menor interesse nos visitantes, são estas: a vida noturna, a participação em pesquisas científicas e as atividades com a população local. A falta de interesse por passeios noturnos foi também observada na M.B, onde $48 \%$ dos visitantes relataram não ter interesse (Gráfico 2).

Um percentual pequeno, de $13 \%$ dos visitantes, ainda citou e avaliou outras alternativas de atividades, as quais seguem descritas no Gráfico (3), dentre as opções elencadas pelos visitantes, destacou-se o grau de "muito interesse" e "interesse" pelo rapel, as outras atividades não expressam um interesse significativo e ainda há aquelas que não teriam as mínimas condições de serem desenvolvidas, principalmente pelas incompatibilidade com as características naturais da área, como por exemplo: um tobogã e um restaurante na Cachoeira do Pinga.

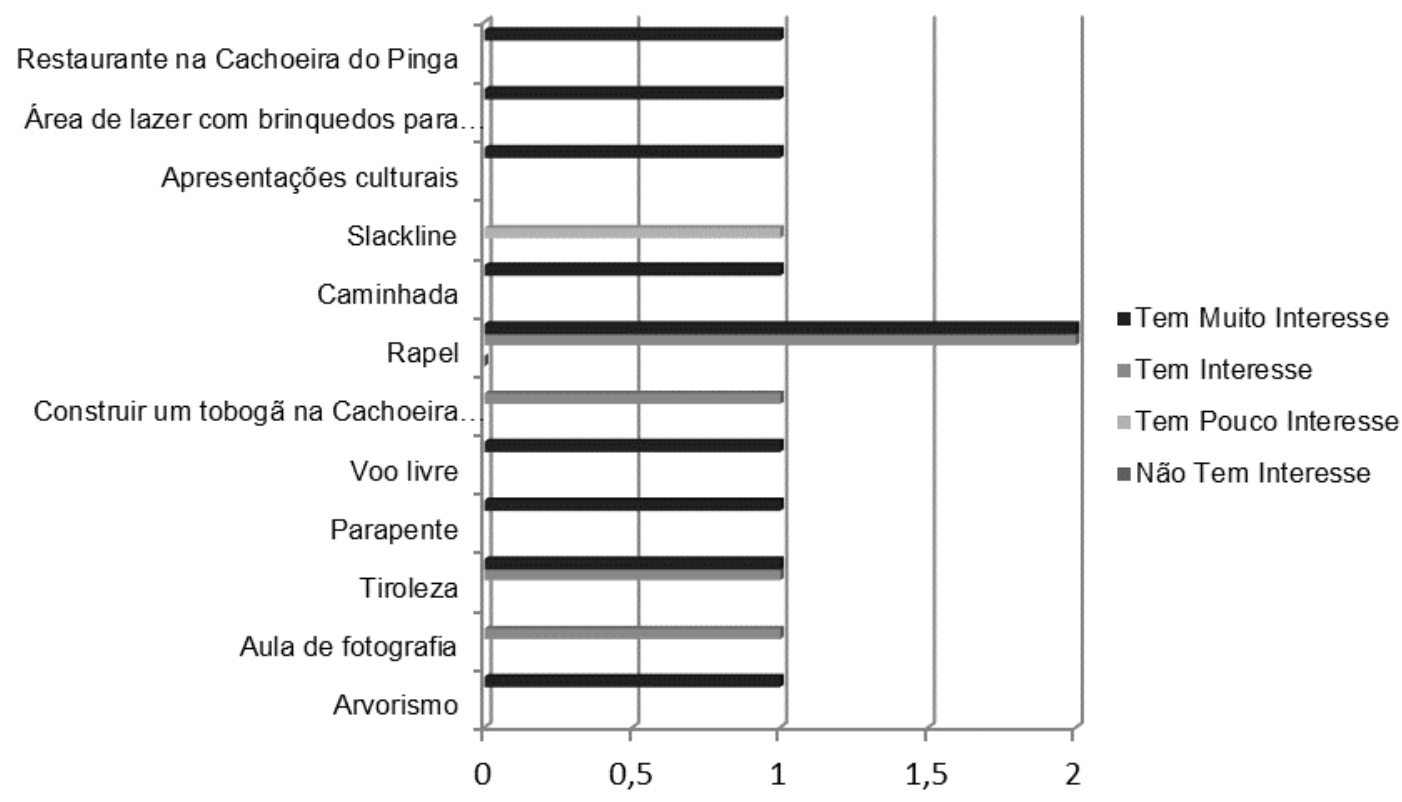

Gráfico 3: Outras opções de atividades elencadas pelos visitantes.

Graph 3: Other options for activities listed by visitors.

É certo que o planejamento da visitação e das alternativas de uso não deve se basear apenas nos anseios dos turistas, para isso o Ministério do Meio Ambiente (MMA) estabelece alguns princípios fundamentais, são estes: o planejamento e a gestão da visitação deverão estar de acordo com os objetivos de manejo da Unidade de Conservação; a visitação é instrumento essencial para aproximar a sociedade da natureza e despertar a consciência da importância da conservação dos ambientes e processos naturais; a visitação deve ser promovida de forma democrática; as atividades de visitação possíveis de serem desenvolvidas em Unidades de Conservação devem estar previstas em seus respectivos instrumentos de planejamento, para evitar qualquer desenvolvimento de atividades inadequadas à área; o desenvolvimento das atividades de visitação requer a existência de 
infraestrutura mínima; a visitação é uma alternativa de utilização sustentável dos recursos naturais e culturais; a manutenção da integridade ambiental e cultural é essencial para sustentar a qualidade de vida e os benefícios econômicos; a visitação deve contribuir para a promoção do desenvolvimento econômico e social das comunidades locais; a visitação deve procurar satisfazer as expectativas dos visitantes no que diz respeito à qualidade e variedade das experiências, segurança e necessidade de conhecimento; o planejamento e a gestão da visitação devem considerar múltiplas formas de organização da visitação, tais como: visitação individual, visitação em grupos espontâneos, visitação em grupos organizados (MMA, 2006).

Sobre o uso público em UCs, é interessante destacar que este vai variar de categoria para categoria, e dependerá dos objetivos estabelecidos no decreto de criação da UC (SIMONETTI; NASCIMENTO, 2013). Com relação à $A R I E$, esta constitui, na verdade, uma versão menor das APAs, em área pouco ocupada, mas que admite utilização direta de recursos naturais. Por não exigir desapropriação, torna-se, assim como as APAs, uma opção mais barata, para o Poder Público, de instituição de unidade de conservação, que procura conciliar desenvolvimento econômico e proteção do ambiente natural. A possibilidade de visitação na ARIE é flexível, segue a mesma lógica das APAs (LEUZINGER, 2010).

Todavia, Zeller (2012) ao analisar a forma com que o tema "visitação pública" é abordado tanto nos planos de manejo como em documentos correlatos de oito parques nacionais brasileiros, conclui que os documentos não guiam ou estabelecem rumos específicos para o manejo voltado à visitação pública.

Assim, fica clara a necessidade de instrumentos que guiem os princípios da visitação pública em cada UC. Para Zeller (2012), o planejamento do uso público em áreas protegidas deve se concentrar em áreas menores para que sejam desenvolvidas e se possível em locais onde já existe procura. Tal contexto se adequa perfeitamente ao perfil da ARIE Mata da Bica, a qual possui uma extensão territorial relativamente pequena e já possui um fluxo de visitantes significativo.

Logo, é imprescindível um detalhamento técnico mais prático, que ofereça à equipe propostas ou projetos de execução na conjuntura de cada unidade e principalmente delinear quais são os princípios da visitação pública para então definir o que se espera do planejamento do uso público (ZELLER, 2012).

\section{Considerações Finais}

Diante das discussões proferidas no trabalho, nota-se que, quanto ao perfil do visitante e a percepção ambiental dos mesmos, a ARIE Mata da Bica possui um percentual acentuado de jovens e adultos, com idades entre 18 e 59 anos, cujo nível escolar da maioria permeia entre os que concluíram o ensino médio (36\%) e os que concluíram o ensino fundamental (26\%), tais constatações delineiam caminhos a se pensar para o turismo na unidade, 
quais as atividades de lazer são adequadas para as respectivas idades? quais os programas de educação deverão ser contemplados, levando em consideração a idade e o nível escolar?

Apesar de pouco expressivo, os idosos acima de 59 anos compõem $8 \%$ da amostra entrevistada, sendo assim, ressalta-se que as propostas de atividades desenvolvidas na área deverão contemplar os diferentes grupos e seus anseios. É perceptível que há uma expectativa do público jovem de experimentar um turismo de aventura associado à balneabilidade, já o público idoso tende a se concentrar nas atividades de menor risco, como a contemplação paisagística, no entanto, isto não impede que na área haja trilhas e caminhadas acessíveis para este último público.

Os programas de educação ambiental na Unidade devem atender principalmente o nível escolar mais significativo. Há uma preocupação, refletida inclusive em outros trabalhos, acerca do desconhecimento dos visitantes de áreas protegidas sobre o significado do próprio termo "Unidade de Conservação", o desconhecimento é ainda maior quando se pergunta sobre a categoria da unidade. Na Mata da Bica, $79 \%$ não sabem o que significa ARIE.

Partindo deste pressuposto, cabe aos programas de educação ambiental o desafio de sensibilizar os visitantes a respeito do que consiste 0 ambiente ecológico da Mata da Bica, qual a sua função e importância no bioma caatinga. A abordagem ambiental feita ao visitante logo no início de sua visita o fará ver e usufruir do espaço com mais responsabilidade.

No que diz respeito ao uso público, a ARIE Mata da Bica, apesar de não dispor ainda de um plano de manejo, possui uma dinâmica de uso, a qual é constituída pelas práticas que foram produzidas pelos próprios visitantes e pela comunidade local ao longo do tempo, como o banho na Cachoeira do Pinga, o banho na bica do TTB, piqueniques e contemplação paisagística, entre outros. Estes usos são desenvolvidos de maneira independente, sem acompanhamento de profissionais ou autorização. Contudo, ressalta-se que a partir do momento em que o uso público passar a integrar a política de manejo da ARIE, deve respeitar o objetivo da categoria que é manter o ecossistema natural de importância regional e local e regular o uso admissível da área, de modo a compatibilizá-lo com os objetivos de conservação da natureza.

Para tanto, destaca-se as possibilidades de uso indicadas pelos especialistas consultados no trabalho, uma vez que estas visam atender, da melhor forma, o viés conservacionista da área e o viés social, tornando a área mais atrativa para o turista. Do ponto de vista do visitante, as atividades que mais despertam o interesse são: o banho em riachos e cachoeiras, a observação da fauna e flora e a contemplação paisagística, tais opções coicidem com a opinião dos especialistas e são passíveis de regulamentação pelo poder público, uma vez que não demandam um suporte técnico e estrutural significativo. Diante do exposto, acredita-se que o diagnóstico do uso público aqui discutido contribuirá com a construção de uma política de regulação e gestão coerente com a dinâmica local da ARIE Mata da Bica. 


\section{Referências}

ARAMAYO, J.L.S; PERALES, W.J.S. Valoração econômica do Parque Estadual das Dunas (Natal-RN). In: XXX ENCONTRO NACIONAL DE ENGENHARIA DE PRODUÇÃO: Maturidade e desafios da Engenharia de Produção: competitividade das empresas, condições de trabalho, meio ambiente. São Carlos, Anais... São Carlos: São Paulo, Brasil,2010.

ARAÚJO, H.R; OLIVEIRA-JÚNIOR, A.F; AZEVEDO, A.A. Percepções e perfil socioeconômico dos visitantes e da comunidade local para o desenvolvimento do espeleoturismo em um atrativo natural em Minas Gerais. Revista Brasileira de Ecoturismo, São Paulo, v.8, n.4, ago/out 2015, pp.462-481.

BRASIL. Decreto no 4.340, de 22 de agosto de 2002. Regulamenta artigos da Lei no 9.985, de 18 de julho de 2000, que dispõe sobre o Sistema Nacional de Unidades de Conservação da Natureza - SNUC, e dá outras providências. Diário Oficial da União. Brasília, 23 ago, 2002.

BELLINASSI, S.; PAVÃO, A.C.; CARDOSO-LEITE, E. Gestão e Uso Público de Unidades de Conservação: um olhar sobre os desafios e possibilidades. Revista Brasileira de Ecoturismo, São Paulo, v.4, n. 2, 2011, p. 274-293. Disponível em: $<$ http://www.sbecotur.org.br/rbecotur/seer/index.php/ecoturismo/article/view/13 2>. Acesso em: 11 ago. de 2016.

CAMPOS, R.F; VASCONCELOS, F.C.W; FÉLIX, L.A.G. A Importância da Caracterização dos Visitantes nas Ações de Ecoturismo e Educação Ambiental do Parque Nacional da Serra do Cipó/MG. Turismo em análise. v.22, n. 2. Agosto. p.397-427. 2011.

CASTILHO, C.T. GOMES, C.L. The Role of Professionals in Two NatureBased Activities in Brazil for Visitors' Connection with nature: Rock Climbing and Birdwatching. Revista Brasileira de Ecoturismo, São Paulo, v.10, n.1, fev/abr 2017, pp.93-112.

HEARNER, R.R; SALINAS, Z.M. The use of choice experiments in the analysis of tourist preferences for ecotourism development in Costa Rica. J. Environ Manage. v. 65, n. 2. p. 63-153. 2002.

KITAGAWA, A. T; COSTA, M. C; LIMA, L. J. M; KITAGAWA, M. G; AGUIAR, H; SALLES, R. O. L; SILVA, N. C. S. Perfil dos visitantes do Parque Natural Municipal da Taquara, Duque de Caxias, RJ. Universidade Federal Fluminense. Niterói: Rio de Janeiro. Anais... n.1, v. 1, p.192-199. 2013.

LARSON, L.R; CONWAY, A.L; KRAFTE, K.E; HERNANDEZ, S.M; CARROLL, J.P. Community-based conservation as a potential source of conflict around a protected area in Sierra Leone. Environmental Conservation. v. 43, n. 3. 2016. p. $242-252$.

LEUZINGER, M.D. Uso Publico em Unidades de Conservação. 2010. 19 p. Disponível

em:<http://www.nima.pucrio.br/aprodab/artigos/uso publico em unidades de conservacao marcia leuzinger.pdf> Acesso em: 04 mar. 2017. 
MARTINS, A.L.L. Lazer e área protegida: conflitos na busca de "emoções agradáveis". Ambient. soc. vol.14 , n. 2, São Paulo, Jul/Dez. p. 51-67. 2011.

MEDEIROS, R; YOUNG, C.E.F; PAVESE, H.B; ARAÚJO, F.F.S. Contribuição das unidades de conservação brasileiras para a economia nacional: sumário executivo. Brasília: UNEP-WCMC, 2011, 44 p.

MELO, R.S; LINS, R.P.M; ELOY, C.C. O Impacto do Turismo em Ambientes Recifais: Caso Praia Seixas-Penha, Paraíba, Brasil. REDE - Revista Eletrônica do Prodema, v.8, n.1, p. 67-83, abr. 2014, Fortaleza, Brasil, ISSN: 1982-5528

MMA. MINISTÉRIO DO MEIO AMBIENTE. Diagnóstico da visitação em parques nacionais e estaduais. Brasília: Ministério do Meio Ambiente. Secretaria de Biodiversidade e Florestas, 2005.

MMA. MINISTÉRIO DO MEIO AMBIENTE. Diretrizes para visitação em Unidades de Conservação. Brasília: Ministério do Meio Ambiente, 2006, 61p. Disponível em: $<$ http://www.mma.gov.br/estruturas/ascom boletins/ arquivos/livro.pdf>.

Acesso em: 11 ago. de 2016.

MMA. Ministério do Meio Ambiente. O Sistema Nacional de Unidades de Conservação da Natureza. Brasília: MMA. 2011. Disponível em: < http://www.mma.gov.br/estruturas/sbf2008 dap/ publicacao/149 publicacao0 5072011052951.pdf> Acesso em: 30 ago. 2016.

MMA. Ministério do Meio Ambiente. Tabela consolidada das Unidades de Conservação. Brasília. 26 fev. 2016a. Disponível em: $<$ http://www.mma.gov.br/images/arquivo/80112/CNUC ConsolidadoFev16.pdf > Acesso em: 20 ago. 2016.

MMA. Ministério do Meio Ambiente. Unidades de Conservação por Bioma. Brasília. 26 fev. 2016b. Disponível em: <http://www.mma.gov.br/images/arquivo/80112/CNUC PorBiomaFev16.pdf> Acesso em: 30 ago. 2016.

MMA. Ministério do Meio Ambiente._Educação ambiental em unidades de conservação: ações voltadas para comunidades escolares no contexto da gestão pública da biodiversidade. 2016. ISBN 978-85-5574-031-2. Disponível em:

$<$ http://www.icmbio.gov.br/portal/images/stories/comunicacao/publicacoes/pub licacoes-

diversas/DCOM ICMBio educacao ambiental em unidades de conservaca o.pdf> Acesso em: 08 mar. 2016.

NASCIMENTO, S.T.M.F; RIBEIRO, E.S; SOUSA, R.A.T.M. Valoração econômica de uma unidade de conservação urbana, Cuiabá, Mato Grosso. Interações. Campo Grande, v. 14, n. 1, p. 79-88, jan./jun. 2013.

OLIVEIRA, M.P; FERREIRA, E; RIBEIRO, M; SOUZA, J; RICHTER, M. Perfil, percepção e opinião dos visitantes do parque nacional do Itatiaia (RJ) em períodos de maior demanda. II Encontro Fluminense de Uso Público em Unidades de Conservação. Turismo, recreação e educação: caminhos que se cruzam nos parques. Universidade Federal Fluminense. Niterói: Rio de 
Janeiro. Anais... $2015 . \quad$ Disponível em: $<$ http://www.uff.br/var/www/htdocs/usopublico/images/Artigos/2015/art17 201 5.pdf > Acesso em: 01 fev. 2017.

PONTES, J.A.L; MELLO, F.A.P. Uso público em unidades de conservação de proteção integral: considerações sobre impactos na biodiversidade. Universidade Federal Fluminense. Niterói: Rio de Janeiro. Anais... n.1, v. 1, p.221-223. 2013.

RANDRIANARISON, H; WÄTZOLD, F. Are buyers of forest ecosystem services willing to consider distributional impacts of payments to local suppliers? Results from a choice experiment in Antananarivo, Madagascar. Environmental Conservation. v. 44, n. 1. 2016. p. 1-8. doi: 10.1017/S0376892916000540.

SILVEIRA, I.M.M.; CARVALHO, R.G. Microclimate and thermal comfort in the Mata da Bica area, in the municipality of Portalegre / RN. Revista Brasileira de Geografia Física, v. 9, p. 62-78, 2016.

SIMONETTI, S.R.; NASCIMENTO, E.P. Uso público em unidades de conservação: fragilidades e oportunidades para o turismo na utilização dos serviços ecossistêmicos. Somanlu: Revista de Estudos Amazônicos, v. 12, n. $1, \quad$ p. 173-190, 2013. Disponível em: $<$ http://www.periodicos.ufam.edu.br/index.php/somanlu/article/view/465/295>. Acesso em: 12 ago. de 2016.

SOUZA, P.C.; MARTOS, G.L. Estudo do Uso Público e Análise Ambiental das trilhas em uma Unidade de Conservação de Uso Sustentável: Floresta Nacional de Ipanema, Iperó - SP. R. Árvore, Viçosa-MG, v.32, n.1, p. 91-100, 2008.

SOUZA, T.V.S.B.; BORBA, M.V.G. Dados da visitação nos parques nacionais brasileiros. In: VIII Congresso Nacional de Ecoturismo e do IV Encontro Interdisciplinar de Ecoturismo em Unidades de Conservação. Anais...Revista Brasileira de Ecoturismo, São Paulo, v.4, n.4, 2011, p. 639.

SOUZA, T.V.S.B. Avaliação da oferta, demanda e impactos econômicos do turismo em unidades de conservação federais do Brasil. 2016. $201 \mathrm{f}$. Tese (Doutorado em Ecologia). Universidade das Florida, Estados Unidos. 2016. Disponível em: <https://www.academia.edu/30477468/RECREATION CLASSIFICATION TO URISM DEMAND AND ECONOMIC IMPACT ANALYSES OF THE FEDE RAL PROTECTED AREAS OF BRAZIL> acesso em: 08 mar. 2017.

TAKAHASHI, L. Uso público em unidades de conservação. Cadernos de Conservação: Fundação o Boticário de Proteção à natureza. Ano 2, n. 2. 2004.

VALLEJO, L.R. Uso público em áreas protegidas: atores, impactos, diretrizes de planejamento e gestão. Universidade Federal Fluminense. Niterói: Rio de Janeiro. Anais... n.1, v. 1, p.13-26. 2013. 
VOLANOVA, S.R.F; CHICHORRO, J.F; ARRUDA, C.A.S. Disposição a pagar pelo uso de unidades de conservação urbanas: Parque da Cidade Mãe Bonifácia, Cuiabá-MT. Interações (Campo Grande). v.11, n.1, Jan./Jun., $2010 . \quad$ Disponível em: $<$ http://www.scielo.br/scielo.php?script=sci arttext\&pid=S151870122010000100005> Acesso em: 03 fev. 2017.

ZELLER, R. H. Planejamento da visitação pública em oito parques nacionais brasileiros: oportunidades para ajustes. Nature and Conservation, v. 5, n. 2, p. 6-18, 2012. Disponível em: $<$ http://sustenere.co/journals/index.php/nature/article/viewArticle/262>. Acesso em: 09 ago. de 2016.

Samylle Ruana Marinho de Medeiros: Centro Estadual de Educação Profissional Professor Francisco de Assis Pedrosa, Mossoró, RN, Brasil.

E-mail: samyllemedeiros@yahoo.com

Link para o currículo Lattes: http://lattes.cnpq.br/1181270769862589

Rodrigo Guimarães de Carvalho: Universidade do Estado do Rio Grande do Norte, Mossoró, RN, Brasil.

E-mail: rodrigo.ufc@gmail.com

Link para o currículo Lattes: http://lattes.cnpq.br/4013877101488981

Geraldo Braz Silva Santos: Universidade do Estado do Rio Grande do Norte, Mossoró, RN, Brasil.

E-mail: g.braz.uern@gmail.com

Link para o currículo Lattes: http://lattes.cnpq.br/6789696390336915

Louize Nascimento: Universidade do Estado do Rio Grande do Norte, Mossoró, RN, Brasil.

E-mail: louizenascimento@live.com

Link para o currículo Lattes: http://lattes.cnpq.br/2885835172826380

Francisco Hiályson Fidelis Medeiros: Universidade do Estado do Rio Grande do Norte, Mossoró, RN, Brasil.

E-mail: hialysonfidelis@gmail.com

Link para o currículo Lattes: http://lattes.cnpq.br/2099630827738541

Antônio Helton da Silva Barbosa: Universidade do Estado do Rio Grande do Norte, Mossoró, RN, Brasil.

E-mail: Helton_asb@hotmail.com

Link para o currículo Lattes: http://lattes.cnpq.br/4351710952484160

Data de submissão: 31 de janeiro de 2018

Data de recebimento de correções: 02 de abril de 2018

Data do aceite: 04 de abril de 2018

Avaliado anonimamente 